\title{
Penentuan Beberapa Karakteristik Fisik dan Mekanik Buah Merah (Pandanus conoideus L.) Sebagai Dasar Perancangan Peralatan Pengolahan Minyak Buah Merah
}

\author{
Determining of Some Physical and Mechanical Properties of Red Fruit (Pandanus \\ conoideus L.) as Basic of Designing of Red Fruit Oil Processing Equipment
}

\author{
Wilson Palelingan Aman ${ }^{1 *}$, Eduard F. Tethool ${ }^{2}$, Zita L. Sarungallo ${ }^{2}$, O’mega Hutabalian ${ }^{3}$ \\ ${ }^{1}$ Program Studi Teknik Pertanian dan Biosistem Universitas Papua \\ Jl. Gunung Salju Amban, Manokwari 98314 \\ ${ }^{2}$ Program Studi Teknologi Hasil Pertanian Universitas Papua \\ Jl. Gunung Salju Amban, Manokwari 98314 \\ ${ }^{3}$ Alumni Program Studi Teknologi Hasil Pertanian Universitas Papua \\ *Email: w.palelingan@unipa.ac.id
}

\begin{abstract}
This study aimed to obtain the physical and mechanical data needed in designing red fruit oil processing equipment. Physical and mechanical parameters measured were length, diameter, mass, volume and density of fruit. Physical characterization was carried out on parts of the fruit which include whole fruit (cepallum), fruit heardwood (pedicel) and fruit seeds (drupa). Physical and mechanical characteristics of measurements of whole red fruit (cepallum) included average length of $71.50 \mathrm{~cm}$, average mass of $4.72 \mathrm{~kg}$, average volume of $5.66 \times 10^{-3}$ $\mathrm{m}^{3}$ and average density of $835.09 \mathrm{~kg} / \mathrm{m}^{3}$. The results of measurement of physical and mechanical characteristics of fruit pith (pedicel) included average length of $69.25 \mathrm{~cm}$, average mass of $2.50 \mathrm{~kg}$, average volume of $3.27 \times 10^{-3} \mathrm{~m}^{3}$ and average density of $770.70 \mathrm{~kg} /$ $\mathrm{m}^{3}$. For the fruit seeds (drupa), the average mass, the average volume, and the average density were $2.2 \mathrm{~kg}, 2.39 \times 10^{-3} \mathrm{~m}^{3}$ and $927.11 \mathrm{~kg} / \mathrm{m}^{3}$ respectively. Based on the results of the study, it was known that the largest percentage of red fruit was fruit pedicel, which was an average of $57.72 \%$.
\end{abstract}

Keywords: Physical properties, mechanical, red fruit (P. conoideus L.), design.

\begin{abstract}
Abstrak
Penelitian ini bertujuan untuk mendapatkan data-data fisik dan mekanik yang diperlukan dalam merancang peralatan-peralatan pengolahan minyak buah merah. Parameter fisik dan mekanik yang diukur adalah panjang, diameter, massa, volume dan densitas buah. Karakterisasi fisik dilakukan terhadap bagian buah yang meliputi buah utuh (cepallum), empulur buah (pedicel) dan bulir buah (drupa). Karakteristik fisik dan mekanik hasil pengukuran cepallum adalah panjang rata-rata $71,50 \mathrm{~cm}$, massa rata-rata $4,72 \mathrm{~kg}$, volume rata-rata $5,66 \times 10^{-3} \mathrm{~m}^{3}$ dan densitas rata-rata sebesar $835,09 \mathrm{~kg} / \mathrm{m}^{3}$. Hasil pengukuran karakteristik fisik dan mekanik pedicel adalah panjang rata-rata $69,25 \mathrm{~cm}$, massa rata-rata $2,50 \mathrm{~kg}$, volume rata-rata $3,27 \times 10^{-3} \mathrm{~m}^{3}$ dan densitas rata-rata sebesar $770,70 \mathrm{~kg} / \mathrm{m}^{3}$. Untuk bagian drupa yaitu massa rata-rata $2,2 \mathrm{~kg}$, volume rata-rata $2,39 \times 10^{-3} \mathrm{~m}^{3}$ dan densitas ratarata sebesar $927,11 \mathrm{~kg} / \mathrm{m}^{3}$. Berdasarkan hasil penelitian diketahui bahwa persentase volume terbesar buah merah adalah pedicel buah yaitu rata-rata $57,72 \%$.
\end{abstract}

Kata kunci: Sifat fisik, mekanik, buah merah (P. conoideus L.), perancangan. 


\section{PENDAHULUAN}

Pemanfaatan buah merah sebagai bahan pangan dapat dilakukan dengan mengkonsumsi buah langsung atau melalui ekstraksi minyak dari buah. Minyak buah merah selanjutnya dapat diolah menjadi berbagai bentuk produk pangan fungsional. Minyak buah merah sendiri diketahui mengandung berbagai komponen aktif seperti $\alpha$-karoten, $\beta$-karoten, $\beta$ kriotosantin, $\alpha$-tokoferol, asam lemak bebas (Murtiningrum dkk., 2005, Rohman dkk., 2012). Proses ekstraksi minyak buah merah dapat dilakukan secara tradisional atau menggunakan peralatan pengolahan yang sesuai.

Proses perancangan alat dan mesin pengolahan pangan memerlukan ketersediaan informasi tentang karakteristik fisik dan mekanik bahan. Pengetahuan akan sifat-sifat fisik bahan merupakan data rekayasa yang penting dan esensial dalam perancangan mesin, struktur, proses dan kontrol; dalam analisis dan penentuan efisiensi dari sebuah mesin atau operasi (Mohsenin, 1970). Pentingnya studi mengenai sifat-sifat fisik dan mekanis bahan pangan adalah untuk meminimumkan kerusakan, sifat-sifat tersebut dipertimbangkan sebagai data dasar dalam perancangan mesin dan peralatan yang digunakan selama pemanenan dan dalam operasi-operasi pascapanen (Jahanbakhshi dkk., 2018).

Karakteristik fisik buah merah merupakan indikator awal penting, karena informasi sifat fisik bahan pangan menentukan aplikasi teknologi yang tepat untuk digunakan dalam proses pengolahannya. Pengamatan terhadap parameter sifat fisik buah merah secara kualitatif seperti warna, kekerasan dan bentuk buah merah yang diamati secara visual serta secara kuantitatif seperti bobot dan ukuran buah merah pada 3 klon buah merah yang diukur berdasarkan 3 titik yaitu pangkal, tengah dan ujung pada buah merah telah dilakukan oleh Keroman (2013). Hal ini sejalan dengan penelitian Sarungallo dkk. (2019) yang menjelaskan bahwa karakterisasi sifat fisik buah merah utuh dapat dilakukan dengan mengamati bentuk, warna, panjang, massa, dan keliling lingkar buah dengan mengukur massa dan keliling lingkar buah merah berdasarkan 3 titik yaitu pangkal, tengah dan ujung buah merah. Karakteristik fisik buah dari kedua penelitian tersebut, belum dapat menjadi dasar dalam perancangan peralatan pengolahan buah merah, karena keterbatasan parameter dan kekurangakuratan cara pengukuran.

Untuk merancang peralatan-peralatan pengolahan, beberapa parameter fisik dan mekanik buah merah lain yang perlu ditentukan antara lain volume dan massa jenis buah merah. Selain karena kurangnya informasi mengenai karateristik fisik buah merah, teknik pengukuran dimensi fisik buah yang digunakan oleh Keroman (2013) dan Sarungallo dkk. (2019) dinilai kurang akurat untuk menentukan besaran volume buah merah. Hal ini disebabkan oleh bentuk buah yang cenderung berbentuk kerucut dimana masing-masing titik (ujung sampai pangkal) memiliki diameter yang berbeda-beda.

Salah satu cara untuk mengurangi kehilangan dalam produksi adalah melalui penelitian sifat-sifat fisik dan mekanik produkproduk pertanian (Jahanbakhshi, 2018). Informasi mengenai sifat fisik dan mekanik buah merah dapat berpengaruh terhadap penggunaan teknologi yang digunakan, karena berkaitan dengan prinsip kerja alat hingga kapasitas alat yang digunakan. Selain itu dapat menjadi dasar dalam perancangan sistem penyimpanan dan pengangkutan. Oleh karena itu, investigasi terhadap karakteristik fisik dan mekanik buah merah perlu dilakukan. Tujuan penelitian ini adalah untuk memdapatkan data karakteristik fisik dan mekanik buah merah sebagai data dasar dalam perancangan peralatan pengolahan dan proses pascapanen yang terkait. Lebih jauh diharapkan dapat menjadi dasar pengembangan teknologi berbasis buah merah sebagai salah satu komoditi andalan lokal daerah Papua.

\section{METODOLOGI}

\section{Bahan dan alat}

Bahan utama yang digunakan pada penelitian ini yaitu buah merah jenis Edewewits, Memeri dan Hibcau yang diambil dari kebun percobaan UNIPA. Peralatan yang digunakan meliputi timbangan, wadah penampang dan penggaris.

\section{Persiapan sampel buah merah}

Buah merah yang digunakan merupakan buah merah matang, kemudian lakukan pembersihan pada kotoran yang menempel 
pada buah merah. Selanjutnya letakkan buah merah pada tempat yang aman sehingga terhindar dari benturan yang mengakibatkan kerusakan fisik pada buah merah.

\section{Karakterisasi sifat fisik dan mekanis buah merah.}

Karakteristik fisik buah merah yang menjadi parameter dalam penelitian ini adalah warna, massa, panjang, bentuk penampang, keliling buah, volume, dan massa jenis. Karakteristik fisik Buah Merah dilakukan terhadap 3 bagian (cepallum, pedicel dan drupa). Tahapan karakterisasi sifat fisik buah merah adalah sebagai berikut :

1. Karakterisasi warna buah yang dilakukan melalui pengamatan visual.

2. Pengukuran massa buah dilakukan melalui penimbangan dan dinyatakan dalam satuan kilogram (kg).

3. Pengukuran panjang buah dilakukan dengan cara mengukur panjang dari pangkal hingga ujung buah dan dinyatakan dalam satuan meter $(\mathrm{m})$.

4. Penentuan bentuk penampang buah yang dilakukan melalui pendekatan geometris. Bentuk geometri buah selanjutnya menetukan volume buah. Penentuan bentuk penampang dilakukan melalui pengamatan secara visual.

5. Pengukuran keliling penampang buah dilakukan sebagai dasar penentuan luas permukaan dan volume buah. Keliling buah diukur menggunakan alat ukur panjang (meteran) dan dinyatakan dalam satuan meter $(\mathrm{m})$.

6. Penentuan volume dilakukan melalui perhitungan dengan Persamaan 1 :

$$
V=A x t .
$$

V: volume buah $\left(\mathrm{m}^{3}\right)$

A: luas penampang buah $\left(\mathrm{m}^{2}\right)$ $\mathrm{t}$ : tinggi atau panjang buah $(\mathrm{m})$

7. Penentuan densitas (massa jenis) buah dilakukan melalui perhitungan menggunakan Persamaan 2.

$$
\begin{aligned}
& \rho=\frac{m}{V} \\
& \rho: \text { densitas buah }\left(\mathrm{kg} / \mathrm{m}^{3}\right) \\
& \text { M: massa buah }(\mathrm{kg}) \\
& \text { V: volume Buah }\left(\mathrm{m}^{3}\right)
\end{aligned}
$$

\section{HASIL DAN PEMBAHASAN}

Buah merah utuh (cepallum) terdiri dari empulur (pedicel) di bagian tengah dan sekumpulan bulir (drupa) yang tersusun rapat dan menempel kuat pada sisi bagian luar pedicel. Buah merah yang digunakan pada penelitian ini merupakan buah matang berjumlah 6 buah yang terdiri atas 3 jenis yaitu Edewewits, Memeri, Hibcau.

\section{Karakteristik Buah Merah Utuh (Cepallum) \\ Warna cepallum dari 6 buah merah yang} digunakan dalam penelitian ini adalah merah. Tingkat kematangan buah merah mempengaruhi warna pada buah yang ditandai dengan perubahan warna buah dari warna hijau, merah muda, merah pucat saat buah muda dan menjadi merah kehitaman saat buah matang (Santoso dkk., 2011). Kontribusi warna merah pada buah merah diindikasikan akibat adanya pembentukan karotenoid secara maksimal (Sarungallo dkk., 2016). Identifikasi warna buah berkaitan erat dengan kualitas buah merah. Ketepatan dalam mengidentifikasi warna buah merah yang matang optimum, dapat menentukan kualitas maupun kuantitas minyak buah merah yang dihasilkan dalam proses ekstraksi. 


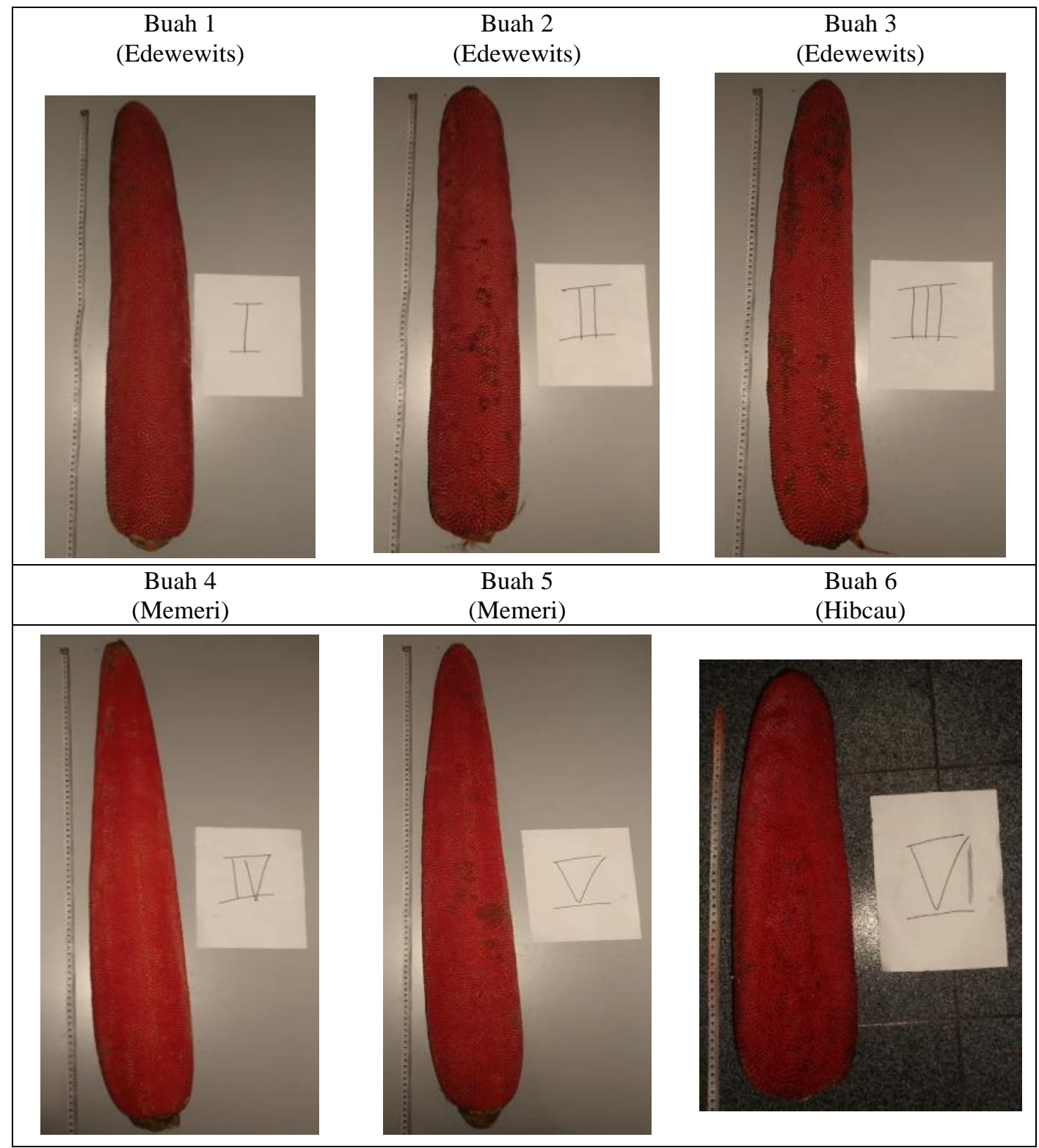

Gambar 1. Cepallum dari beberapa jenis buah merah.

Bentuk penampang cepallum umumnya menyerupai prisma segitiga tetapi dengan sisisisi yang tidak membentuk garis lurus sehingga lebih mendekati bentuk lingkaran. Dalam bentuk tiga dimensi, bentuk cepallum menyerupai silinder meruncing dari pangkal buah. Karakter fisik tersebut sejalan dengan hasil pengamatan Sarungallo dkk., (2019) yang menyampaikan bahwa cepallum dapat digambarkan berbentuk silinder meruncing dari pangkal membulat memanjang sampai ke bagian tengah membesar atau mengecil sampai ke bagian ujung mengecil. Pembentukan buah merah terjadi setelah tanaman memasuki fase generatif. Periode pembentukan buah merah setiap kultivar berbeda-beda yang diduga dipengaruhi oleh faktor genetiknya Santoso dkk., (2011).

Penentuan bentuk penampang perlu dilakukan karena terkait berkaitan dengan estimasi luas permukaan penampang dan volume buah. Salah satu variabel yang menentukan perhitungan luas permukaan dan volume buah adalah keliling buah. Karena bentuk buah yang membesar ke bagian tengah dari pangkal, kemudian kembali mengecil dari bagian tengah ke ujung, maka pengukuran keliling buah tidak akurat jika hanya dilakukan pada tiga titik (pangkal, tengah dan ujung) seperti yang dilakukan oleh Keroman (2013) dan Sarungallo dkk., (2019). Metode pengukuran lingkaran buah dalam penelitian 
ini dilakukan setiap $3 \mathrm{~cm}$ buah dari pangkal hingga ke ujung buah. Hasil pengukuran keliling buah pada banyak titik pada bagian buah kemudian menjadi dasar perhitungan karakteristik fisik dan mekanis lainnya.

Tabel 1. Karakteristik Fisik dan Mekanik Cepallum Buah Merah Hasil Pengukuran

\begin{tabular}{lcccccc}
\hline Karakteristik Fisik & \multicolumn{7}{c}{ Jenis Buah } \\
\cline { 2 - 7 } Cepallum & $\mathbf{1}$ & $\mathbf{2}$ & $\mathbf{3}$ & $\mathbf{4}$ & $\mathbf{5}$ & $\mathbf{6}$ \\
\hline Panjang $(\mathrm{cm})$ & 71 & 74 & 73 & 80 & 84 & 47 \\
Massa $(\mathrm{kg})$ & 4,6 & 4,7 & 4 & 5,3 & 5,5 & 4,2 \\
Volume $\left(\mathrm{m}^{3}\right)$ & 0,0051 & 0,0056 & 0,0048 & 0,0063 & 0,0069 & 0,0050 \\
Massa Jenis $\left(\mathrm{kg} / \mathrm{m}^{3}\right)$ & 860,00 & 840,03 & 838,36 & 835,92 & 796,62 & 839,62 \\
\hline
\end{tabular}

Panjang cepallum dari 6 buah merah yang digunakan adalah berkisar $47-84 \mathrm{~cm}$ sedangkan massa buah merah berkisar 4-5,5 kg. Murtiningrum dkk. (2012) mengelompokkan buah merah berdasarkan panjang sebagai berikut buah berukuran panjang $(>50 \mathrm{~cm})$, buah berukuran sedang $(49-53 \mathrm{~cm})$ dan buah berukuran pendek $(<35 \mathrm{~cm})$. Berdasarkan massa buah, Hadad dkk. (2006), mengelompokkan buah merah kecil dengan kisaran massa 4-7 kg dan buah besar dengan kisaran massa 5-10 kg. Berdasarkan panjang, buah merah yang digunakan dalam penelitian ini dominan berukuran besar. Sedangkan berdasarkan massa, buah yang digunakan dikelompokkan sebagai buah merah kecil. Identifikasi jenis buah merah yang digunakan dapat ditentukan dengan mengacu pada Sarungallo dkk., (2019). Hasil identifikasi karakter sifat fisik buah merah, maka disimpulkan bahwa buah 1, 2 dan 3 tergolong jenis Edewewits, buah 4 dan 5 tergolong jenis Memeri, sedangkan buah 6 tergolong jenis Hibcau.

Volume cepallum merupakan karakter sifat fisik dari besaran buah yang dipengaruhi oleh pengukuran panjang dan keliling lingkar buah. Volume cepallum dihitung dengan mendefenisikan buah merah berbentuk tabung (silinder) dimana titik pengukuran keliling lingkar diambil dari pangkal hingga ujung buah dan jarak antara titik keliling lingkar digunakan sebagai tinggi. Dari 6 buah merah yang digunakan, rata-rata volume cepallum adalah $0,0057 \mathrm{~m}^{3}$ dan masing-masing buah merah berkisar 0,0048-0,0069 $\mathrm{m}^{3}$.

Penentuan massa jenis pada bahan pangan.merupakan salah satu faktor penting dalam merancang atau menentukan kapasitas bahan dari suatu desain alat yang berkaitan dengan dimensi alat (Srivastava dkk., 2006).
Massa jenis cepallum dipengaruhi oleh pengukuran massa dari setiap besaran volume buah merah. Rata-rata massa jenis dari keenam buah merah adalah $835,09 \mathrm{~kg} / \mathrm{m}^{3}$ dan masingmasing buah berkisar 796,62-860,00 kg/m . Massa jenis buah merah tersebut dapat menjadi dasar dalam perancangan alat ekstraksi minyak buah merah khususnya perencanaan kapasitas alat pengukus buah merah. Dengan mengetahui massa jenis buah, maka jumlah buah merah yang dapat diproses dengan alat pengukus berkapasitas tertentu dapat diperkirakan. Selain untuk perencanaan kapasitas alat pengolahan, pengetahuan akan massa jenis buah merah dapat menjadi dasar dalam memperkirakan kapasitas wadah transportasi atau penyimpanan dalam skala industri. Jahanbakhshi dkk., (2016) menjelaskan bahwa teknik pengolahan dan transportasi yang tepat bagi produk-produk pertanian membutuhkan data presisi yang berkaitan dengan sifat-sifat fisik dari produk seperti bentuk, ukuran, porositas, luas permukan, dan densitas. Densitas dan porositas mempengaruhi beban struktural dan dipertimbangkan sebagai parameter penting dalam perancangan sistem penyimpanan dan pengeringan (Mpotokwane dkk., 2008).

\section{Karakteristik Empulur (pedicel)}

Empulur (pedicel) merupakan bagian tengah dari buah merah utuh (cepallum) dimana pada bagian sisi luar pedicel merupakan tempat menempelnya drupa. Tampilan bentuk empulur Buah Merah hasil penelitian disajikan melalui Gambar 2. Sedangkan karakteristik fisik dan mekanik pedicel dari beberapa jenis buah merah hasil penelitian ini disajikan melalui Tabel 2. Karakteristik fisik tersebut tersebut meliputi warna, bentuk, panjang, volume, massa jenis, dan persentase empulur. 


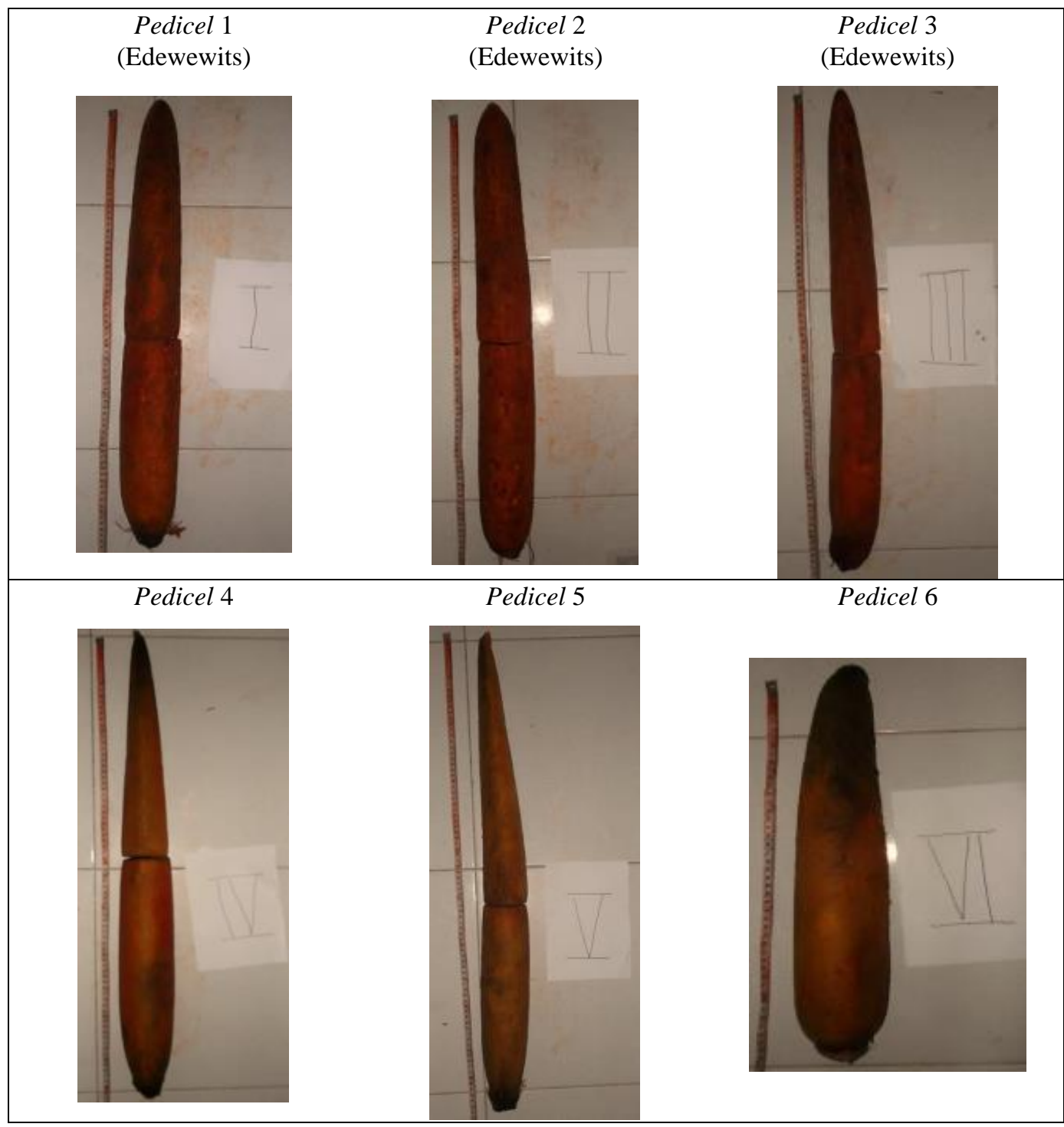

Gambar 2. Empulur (Pedicel) dari beberapa jenis buah merah.

Tabel 2. Karakteristik Fisik dan Mekanik Pedicel Buah Merah.

\begin{tabular}{lcccccc}
\hline \multirow{2}{*}{ Bagian Buah Pedicel } & \multicolumn{7}{c}{ Jenis Buah Merah } \\
\cline { 2 - 7 } & $\mathbf{1}$ & $\mathbf{2}$ & $\mathbf{3}$ & $\mathbf{4}$ & $\mathbf{5}$ & $\mathbf{6}$ \\
\hline Massa $(\mathrm{kg})$ & 2,5 & 2,6 & 2,1 & 2,8 & 2,7 & 2,3 \\
Persentase terhadap & $54 \%$ & $55 \%$ & $53 \%$ & $53 \%$ & $49 \%$ & $55 \%$ \\
massa Cepallum & 0,0031 & 0,0032 & 0,0027 & 0,0039 & 0,0039 & 0,0029 \\
Volume $\left(\mathrm{m}^{3}\right)$ & $57 \%$ & $58 \%$ & $56 \%$ & $61 \%$ & $58 \%$ & $60 \%$ \\
Persentase terhadap & & & & & & \\
volume Cepallum & 818,76 & 802,99 & 792,94 & 723,71 & 675,09 & 770,91 \\
Massa Jenis $\left(\mathrm{kg} / \mathrm{m}^{3}\right)$ & & & & &
\end{tabular}

Hasil pengamatan warna pedicel dari 6 buah merah yang digunakan adalah putih kemerahan. Sarungallo (2014) menyampaikan bahwa warna empulur buah muda lebih putih dibandingkan buah matang yang dipengaruhi oleh warna pipilannya. Dengan demikian, warna putih pada pedicel buah merah 
dipengaruhi oleh klon dan tingkat kematangan buah.

Umumnya pedicel berbentuk silinder segitiga membulat dimana pada ujung cenderung meruncing. Hasil penelitian Sarungallo dkk. (2019) menunjukkan, bahwa bentuk pedicel mempengaruhi bentuk buah cepallum yaitu silinder meruncing dengan ukuran lingkar pangkal lebih kecil dari bagian tengah dan mengecil pada bagian ujung.

Dari 6 buah merah yang digunakan ratarata panjang pedicel adalah $69,2 \mathrm{~cm}$ dengan masing-masing pedicel berkisar 45-81,5 cm. Sarungallo dkk., (2019) menggolongkan perbedaaan ukuran panjang pedicel yaitu panjang $(>50 \mathrm{~cm})$, sedang $(45-50 \mathrm{~cm})$ dan pendek $(<45 \mathrm{~cm})$. Berdasarkan pengelompokkan tersebut, pedicel buah merah jenis 1,2,3,4 dan 5 tergolong perdicel panjang dengan kisaran $69-81,5 \mathrm{~cm}$, sedangkan buah 6 tergolong pedicel sedang yaitu $45 \mathrm{~cm}$. Massa pedicel rata-rata $2,5 \mathrm{~kg}$ dan masing-masing pedicel berkisar 2,1-2,8 $\mathrm{kg}$. Massa tersebut berada dalam kisaran massa hasil penelitian Sarungallo dkk (2019), yang mengukur massa pedicel dari 9 klon buah merah rata-rata berkisar 1-4,6 kg.

Volume pedicel rata-rata $0,0033 \mathrm{~m}^{3}$ dan masing-masing buah berkisar 0,0027-0,0039 $\mathrm{m}^{3}$ dengan persentase pedicel terhadap cepallum rata-rata $58 \%$ dan masing-masing persentase pedicel dari buah yang digunakan berkisar $56-61 \%$. Kisaran persentase pedicel relatif sama dengan laporan Sarungallo (2014) bahwa masing-masing persentase pedicel dari 9 klon buah merah berkisar 51-61\%. Massa jenis (densitas kamba) pedicel rata-rata 770,77 $\mathrm{kg} / \mathrm{m}^{3}$ atau berkisar $675,09-818,76 \mathrm{~kg} / \mathrm{m}^{3}$.
Karakteristik fisik dan mekanis pedicel memberikan informasi potensinya yang besar jika pemanfaataannya diketahui di kemudian hari. Hal ini disebabkan karena pedicel merupakan bagian terbesar dari buah merah.

\section{Karakteristik Fisik Bulir Buah Merah (drupa)}

Drupa merupakan bulir buah merah yang terdiri dari biji yang diselimuti daging buah (pulp) dan menempel di sisi luar pedicel. Panjang drupa buah merah berkisar 1,2 - 1,7 $\mathrm{cm}$. Perbedaan ukuran drupa buah merah dipengaruhi oleh berbagai faktor seperti jenis dan asal buah (Murtiningrum dkk. 2012). Tabel 3 menyajikan karakter fisik drupa yang meliputi warna, massa, volume, massa jenis, dan persentase drupa terhadap cepallum.
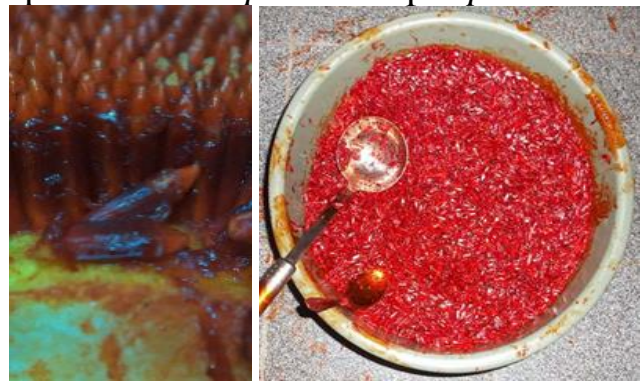

Gambar 3. Drupa dari buah merah

Warna drupa dari buah merah yang digunakan umumnya berwarna merah tua. Hal ini sejalan dengan hasil penelitian Santoso dkk. (2011), yang melaporkan bahwa warna buah kultivar Monsor dan Memeri adalah merah tua mengkilap, sementara kultivar Edewewits adalah merah kehitaman mengkilap. Semakin tinggi tingkat kematangan buah maka warna drupa akan semakin tua/gelap yang menunjukkan meningkatnya kadar karotenoid (Sarungallo dkk., 2016).

Tabel 3. Karakteristik fisik dan Mekanik Drupa Buah Merah

\begin{tabular}{|c|c|c|c|c|c|c|}
\hline \multirow{2}{*}{ Bagian Buah Drupa } & \multicolumn{6}{|c|}{ Jenis Buah Merah } \\
\hline & I & II & III & IV & $\mathbf{V}$ & VI \\
\hline Massa (kg) & 2,1 & 2,1 & 1,9 & 2,5 & 2,8 & 1,9 \\
\hline $\begin{array}{l}\text { Persentase terhadap } \\
\text { massa Cepallum (bulk) }\end{array}$ & $46 \%$ & $45 \%$ & $48 \%$ & $47 \%$ & $51 \%$ & $45 \%$ \\
\hline Volume $\left(\mathrm{m}^{3}\right)$ & 0,0023 & 0,0024 & 0,0021 & 0,0025 & 0,0029 & 0,0020 \\
\hline $\begin{array}{l}\text { Persentase terhadap } \\
\text { volume Cepallum (bulk) }\end{array}$ & $43 \%$ & $42 \%$ & $44 \%$ & $39 \%$ & $42 \%$ & $40 \%$ \\
\hline Massa Jenis bulky $\left(\mathrm{kg} / \mathrm{m}^{3}\right)$ & 41,23 & 37,04 & 45,42 & 112,21 & 121,53 & 68,71 \\
\hline
\end{tabular}


Massa drupa dari 6 buah merah yang digunakan rata-rata $2,2 \mathrm{~kg}$ dengan masingmasing drupa berkisar 1,9-2,8 kg. Massa drupa tertinggi dimiliki buah jenis ke-5 yaitu $2,8 \mathrm{~kg}$ dan massa terendah dimiliki jenis buah ke-3 dan ke-6 yaitu $1,9 \mathrm{~kg}$. Kisaran massa drupa relatif sama dengan laporan Sarungallo dkk., (2019) bahwa berat total bulir (drupa) dari setiap 9 klon buah merah rata-rata berkisar 1-3,3 kg.

Rata-rata volume drupa dari buah merah yang digunakan adalah $0,0024 \mathrm{~m}^{3}$ dan masing-masing volume drupa berkisar 0,0020-0,0029 $\mathrm{m}^{3}$ dengan persentase volume rata-rata $42 \%$ dengan kisaran masing-masing buah 39-45\%. Kisaran tersebut relatif sama dengan hasil penelitian Sarungallo dkk (2019), bahwa masing-masing persentase drupa dari 9 klon buah merah berkisar 39-49\%.

Rata-rata massa jenis drupa dari buah merah yang digunakan adalah 927.11 $\mathrm{kg} / \mathrm{m}^{3}$ dan masing-masing drupa berkisar 836,09-1.011,57 kg/m³. Pengetahuan akan nilai massa jenis bahan penting karena dapat menjadi dasar menentukan aplikasi teknologi yang tepat digunakan (Srivastava dkk. 2006). Massa jenis drupa dapat menjadi dasar dalam menentukan volume alat dalam mengekstraksi massa drupa yang digunakan pada alat pengempaan berbasis buah merah dan perancangan peralatan pemisah daging buah merah dari biji.

\section{KESIMPULAN}

Hasil pengukuran karakteristik fisik dan mekanik Buah Merah yaitu cepallum mempunyai panjang berkisar $47-84 \mathrm{~cm}$, massa berkisar 4-5,5 kg, volume berkisar 0,0048$0,0069 \mathrm{~m}^{3}$, dan massa jenis berkisar 796,62$860,00 \mathrm{~kg} / \mathrm{m}^{3}$. Pedicel mempunyai panjang berkisar 45-81,5 cm, massa berkisar 2,1-2,8 $\mathrm{kg}$, volume berkisar 0,0027-0,0039 $\mathrm{m}^{3}$, dan massa jenis berkisar 675,09-818,76 kg/m . Drupa mempunyai panjang per bulir berkisar 1,2-1,7 cm, massa per buah berkisar 1,9-2,8 $\mathrm{kg}$, volume per buah berkisar 0,0020-0,0029 $\mathrm{m}^{3}$, dan massa jenis berkisar 836,09-1.011,57 $\mathrm{kg} / \mathrm{m}^{3}$.
Karakteristik fisik dan mekanik buah merah dapat menjadi dasar dalam perancangan peralatan pengolahan dan sistem penanganan pascapanen buah merah.

\section{UCAPAN TERIMA KASIH}

Peneliti mengucapkan terima kasih kepada Kementerian Riset dan Teknologi Pendidikan Tinggi - Republik Indonesia, atas bantuan dana penelitian yang diberikan melalui Hibah Penelitian Strategis Nasional tahun 2014.

\section{DAFTAR PUSTAKA}

Hadad, M., Atekan, Malik, A. dan Wamaer, D., (2006), Karakteristik dan potensial tanaman buah merah (Pandanus conoideus Lamk.) di Papua. Prosiding Seminar Nasional BPTP Papua, Jayapura 24-25 Juli, 2006. pp. 243-255.

Jahanbakhshi, A., (2018), Determination of Some Engineering Properties of Snake Melon (cucumis melo var. flexuosus) Fruit. CIGR Journal, 20 (1), pp. 171176.

Jahanbakhshi, A., Yeganeh, R., Yamchi , A.A., (2016), Determination of Physical, Mechanical and Hydrodynamic Properties of Scolymus. Electronic Journal Food Processing and Preservation (EJFPP), 8(1), pp. 125141.

Jahanbakhshi, A., Gilandeh, Y.A., and Gundoshmian, T. M., (2018), Determination of Physical and Mechanical Properties of Carrot in Order to Reduce Waste during Harvesting and Post-harvesting. Food Science and Nutrition, 6, pp. 1898-1903. DOI:10.1002/fsn3.760.

Keroman, S. (2013). Sifat Fisik Buah Selama Tahap Perkembangan Buah Merah (Pandanus conoideus Lamk.). (Skripsi). Fakultas Pertanian dan Teknologi Pertanian, Universitas Papua. Manokwari.

Mpotokwane, S.M., Gaditlhatlhelwe, E., Sebaka, A., and Jideani, V.A., (2008). Physical properties of bambara groundnuts from Botswana. Journal of Food Engineering. 89(1), pp. 93-98. DOI:10.1016/j.jfoodeng.2008.04.006. 
Mohsenin, N.N., (1970), Physical Properties of Plant and Animal Materials. Gordon and Breach, Science Publisher Ltd. London.

Murtiningrum, Ketaren, S., Suprihatin, dan Kaseno, (2015), Ekstraksi Minyak dengan Metode Wet Rendering dari Buah Pandan (Pandanus conoideus L). Jurnal Teknologi Industri Pertanian, 15(1), pp. 28-33.

Murtiningrum, Sarungallo, Z. L., Mawikere, N.L.,(2012), The Exploration and Diversity of Red Fruit (Pandanus conoideus L.) from Papua Based on its Physical Characteristics and Chemical Composition. Biodiversitas, 13(3), pp. 124-129.

Rohman, A., Sugeng, R., and Che Man, Y. B., (2012), Characterizaton of red fruit (Pandanus conoideus Lam) oil. , 19(2), pp. 563-567.

Santoso, B., Murtiningrum, Sarungallo, Z. L., (2011), Morfologi Buah selama Tahap
Perkembangan Buah Merah (Pandanus conoideus)., 2(6), pp. 23-29.

Sarungallo, Z.L., Murtiningrum, B. Santoso, M.K. Roreng dan R.M.M. Latumahina. 2016. Nutrient Content of Three Clones of Red Fruit (Pandanus conoideus) during the Maturity Development. International Food Research Journal, 23(3), pp. 1217-1225.

Sarungallo, Z.L., Hariyadi, P., Andarwulan, N., dan Purnomo, E.H., (2019). Keragaman Karakteristik Fisik Buah, Tanaman dan Rendemen Minyak dari 9 Klon Buah Merah (Pandanus conoideus). Jurnal Agribisnis Perikanan, 12(1), pp. 70-82.

Srivastava, A.K., Goering, C.E., Rohrbach, R.P. and Buckmaster, D.R., (2006), Engineering Principles of Agricultural Machines ( $2^{\text {nd }}$ Edition). American Society of Agricultural and Biological Engineers. ST Josef, Michigan, USA. 